DOI: 10.34015/2523-4552.2019.3.03

УДК 94(477.83/.86): 343.811-055.2

Черчович I. I.,

кандидат історичних наук,

незалежна дослідниця

e-mail: ivankacherchovych@gmail.com

ORCID ID: 0000-0003-3078-7003

\title{
У ПОШУКАХ СВОГО ГОЛОСУ: ЖІНКИ, ОБВИНУВАЧУВАНІ У ДІТОВБИВСТВАХ, У СХІДНІЙ ГАЛИЧИНІ НА ЗЛАМІ ХІХ-ХХ СТОЛІТЬ (НА ПРИКЛАДІ ОДНІЄЇ ІСТОРІї)
}

У статті проаналізовано кримінальні справи жінок, що були судимі за дітовбивство у кінці XIX - початку XX століття: які стратегії захисту звично обирали підозрювані, в який спосіб у вчиненому злочині віднаходили місце для власної віктимності та як ії̈ використовували? Для цього застосовано метод case studies, щоб на прикладі конкретного випадку - розглянутої Крайовим судом Львова у 1906 році справи Марії Петришак - зобразити найпоширеніші тенденції, характерні для більшості кримінальних проваджень на цю тему.

Ключові слова: жінки; дітовбивство; суд; Східна Галичина кінця ХIX початку ХХ століття.

В статье проанализировано уголовные дела женщин, осужденных за детоубийство в конце XIX - начале XX века: какие стратегии защиты обычно выбирали подозреваемые, каким образом в содеянном преступлении находили место для собственной виктимности и как ее использовали? Для этого применен метод case studies, чтобы на примере конкретного случая - рассматриваемого Краевым судом Львова в 1906 году дела Марии Петришак - изобразить самые распространенные тенденции, характерные для большинства уголовных производств на эту тему.

Ключевые слова: женщины; детоубийство; суд; Восточная Галиция, конец XIX - начало XX веков.

Постановка проблеми. $\mathrm{y}$ 1906 році серед підсудних повітового суду у Раві опинилася 26-літня Марія Петришак. Ї̈̈ арешт відбувся за фактом знаходження тіла немовляти неподалік залізничної станції Жовкви у подвір'ї одного з приватних будинків. Розпочата кримінальна справа, від моменту встановлення Марії- ної причетності до вчинку і до винесення їй судового рішення, на ста двадцяти п'яти сторінках розповідає іï історію - характерну для десятків схожих історій жінок, оскаржених у дітовбивствах на зламі XIXXX століть. Детальні автобіографічні свідчення, що вимагалися від підсудних 3 огляду на потреби слідства, 
допасовані розповідями свідків про них, дають можливість скласти картинку не лише злочинів цих жінок, а й їхнього життя. Поодинокі голоси маргінесу, що пробиваються крізь кримінальну документацію, $є$ чи не єдиною можливістю таким як Марія - жінкам з найнижчих верств тогочасної соціальної драбини, найчастіше неписемним, а відтак в історії «німим»- розповісти про себе.

У цій статті аналізуватиму мову кримінальної документації у стосунку до жінок і одного з найбільш специфічних «жіночих злочинів» - дітовбивства: які стратегії захисту звично обирали підозрювані, в який спосіб у вчиненому злочині віднаходили місце для власної віктимності та як їі використовували? Для цього застосую метод case studies, аби на прикладі конкретного випадку зобразити найпоширеніші тенденції, характерні для більшості справ жінок, судимих за ст. 139 Австрійського кримінального кодексу. Спробую показати як часто позбавлені за замовчуванням здатності вибору, згідно з поширеними уявленнями про обов'язкову природну зумовленість жіночого злочину та про потенційну девіантність кожної, жінки зуміли користати 3 таких суджень. Зроблені тут узагальнення здійснені на основі 80-ти кримінальних справ про дітовбивства, підкидання дітей та аборти, що були розглянуті Крайовим судом Львова у період від 1865-1906рр. (Фонд 152 (Крайовий суд, м. Львів) Центрального державного історичного архіву України у Львові)ํ․ Моя дослідницька гіпотеза буде зосереджена навколо пошуків відповідей на запитання - чи, якщо так, то чому і коли досвідчувана жінками нерівність у соціальному житті ставала їх перевагою у суді?

Постановка завдання. Своєю метою я бачу надати обвинувачуваним жінкам голос [1], спробувати поглянути на них з позиції їх власної дієвості, мовою феміністської критики їх women's agency [2, с. 171]. 3 тим аби зобразити цих жінок активними суб'єктами історичного процесу, у конкретному випадку - агентами кримінального провадження, від якості самозахисту яких у суді залежало багато. Такий підхід контрастує зі звичними характеристиками жінок як об’єктів історії, тобто її «жертв» чи «винятків». 3 розчитуванням мови кримінальних справ стають помітними не лише дискурси, актуальні для галицького суспільства зламу XIX-XX століть (емансипація, націоналізація, політизація суспільства тощо), а що найголовніше те, як ці ідеї артикулювалися у стосунку до його найменш привілейованих верств. Показуючи тим самим в який спосіб судова влада відтворювала традиційні гендерні стереотипи та підтримувала існуючі соціальні дистанції, та як у правовий спосіб легалізовувала їх щоразу більш помітну контроверсійність [3].

Аналіз останніх досліджень i публікацій. Жіноча злочинність у XIX столітті залишається темою малодослідженою. Порівняно невелика увага до жінок-ув'язнених особливо

${ }^{1}$ Кількість без урахування справ про нещасні випадки, що трапилися з дітьми 3 провини їхніх батьків чи опікунів, які в описі фонду зберігання нерідко позначені як дітовбивства, але фактично такими не були. 
помітна на тлі доволі активного наукового зацікавлення інститутом в'язниці та їі мешканцями в останні чотири десятиліття від появи Discipline and Punish: the Birth of the Prison Мішеля Фуко [4]. У стосунку до Галичини дослідники здебільшого цікавилися жінками у якості радше жертв злочинів, аніж їх ініціаторок. Мова йшла, зокрема, про таке поширене на зламі XIX-XX століть явище як «торгівля живим товаром», або ж у контексті таємної (незареєстрованої) участі в занятті проституцією [5]. Частково такий результат продиктований значно меншою кількістю жінок-ув'язнених у порівнянні 3 чоловіками. Для часу, про який мова, відсоток жінок серед злочинців у Галичині коливався в межах 11-15\% [6]. Історіографічна небагатослівність на предмет жіночого тюремного досвіду може бути пояснена і специфікою джерел, якими $є$ кримінальні справи. До найбільш очевидних ризиків роботи з такими документами належить фрагментарність збережених справ і нерівномірність їхньої складу - одні 3 них налічують кілька сотень аркушів, інші - всього декілька сторінок. Попри це, їхню цінність важко переоцінити, вони $€$ чи не єдиним, нам доступним, джерелом у вивченні життєвого досвіду тієї категорії населення, котра в історії, звично, взагалі позбавлена власної нарації. Неписемність як характерна риса абсолютної більшості в'язничних мешканок своїм прямим результатом мала дуже невелику кількість жіночих тюремних наративів. Спогади були характерні, головно, жінкам політично засудженим, що в силу свого статусу та ідейних переконання вважали за потрібне задокументувати свій досвід [7].
Виклад основного матеріалу. Станом на кінець XIX століття злочин дітовбивства пройшов кілька етапів своїх законодавчих трактувань: від «природного» права батьків в Античності до злочину караного тортурами і смертю в Середі віки, до знову помітно пом'якшених його правних наслідків, принесеними в європейські кримінальні кодекси ідеями Просвітництва [8]. Жінки, що потрапляли на лаву підсудних за дітовбивство в Австро-Угорській імперії отримували дуже різні покарання: від найвищої кари - кари смерті, що однак, як правило, завжди замінювалася на десятилітні терміни ув'язнення, - до повного виправдання. Однією з причин таких різниць у присудах, крім різних обставин кожного конкретного злочину, був суд присяжних, діяльність якого з ухваленням редакції Австрійського кримінального кодексу 1873 року ставала суттєво розширена. Задуманий як неодмінний чинник гуманізації права на хвилі «Весни народів», суд присяжних ближче до початку XX століття все частіше ставав критикованим. Головним закидом праводавців була непідготовленість присяжних до призначеної їм ролі, незнання ними самих основ права та детермінуюча емоційність у прийнятті рішень. У справах дітовбивств ця емоційність відігравала чи не найвизначнішу роль. Правник Петро Стебельський у 1889 році у рефераті, виголошеному на Другому з'їзді правників і економістів у Львові, аналізуючи присуди, винесені судом присяжних, стверджував, що у справах дітовбивств «присяжні жаліли долю нещасних матерів, яких до злочину змусила бідність, за ніщо маючи установчі акти» $[9$, s. 265]. 
Такий сентимент, можемо припустити, не без успіху використовували підсудні. Принаймні саме на нього, свого часу, поставила згадана на початку Марія Петришак, вимагаючи чим скоріше перевести свою справу з повітового суду Рави до крайового суду у Львові. За матеріалами слідства Марія при цьому погрожувала, «що якщо її прохання не стане розглянутим, то бажає собі в казні смерть», а також просила «про якнайшвидше провадження слідства, щоб їі справа була судима при найближчій каденції Судів присяжних» 1 [10, арк. 17]. Жінка не з чужих слів знала, на що може розраховувати. Судима одинадцять разів до цього, переважно за дрібні злочини, Марія мала вдосталь нагод ознайомитися 3 особливостями тутешньої системи покарання.

\section{У творенні своєї «сторі»}

Окрему жіночу в'язницю Львів отримав у середині XIX століття. Заклад карний для жінок імені Марії Магдалини знаходився у колишньому домініканському монастирі, заснованому тут на початку XVII століття стараннями однієї 3 місцевих землевласниць - Анни Петроконської. Після секуралізації 1787 р. монастир перейшов у світську власність, а $з 1841$ р. у частині приміщень його келій почали організовувати жіночу в'язницю.

«Магдаленки» - таку світську назву носила в'язниця, урядувалися монахинями милосердя ордену Святого Вінцента де Пауло, у підданство яких тюрма перейшла з 1855 р. [11, k. 1254]. Ймовірно тут утримувалися жінки ув'язнені на тривалий строк. Арешти, як короткотермінові покарання чи досудове слідство, вони відбували, найочевидніше, в чоловічих «Бригідках». Ймовірно саме туди і потрапила Марія Петришак. В її справі розпочався етап так званого «детального слідства» (пол. śledztwa szczegółowego). Згідно 3 тогочасним австрійським законодавством цей етап наступав після підготовчого чи вступного слідства (śledztwa przygotowawczego), упродовж якого встановлювалася достовірність причетності підозрюваної особи до злочину [9, s. 249].

В ході «детального слідства» Марія зізналася, що народжене і вбите нею немовля було ії третьою дитиною. Перших двох хлопчиків вона народила від «парубка Івана», з яким познайомилася на службі в одному 3 господарств, де працювала помічницею. Після смерті матері іiі батько одружився вдруге, і через те, що 3 мачухою стосунки не складалися, Марія рано покинула батьківську хату. Відтак, служба ще з підліткового віку стала ії основним засобом існування. Народжених дітей Марія віддавала на утримання в сім'ю свого брата Дмитра. Однак, у нього діти довго не жили, помирали одне за одним. Третю дитину, за вбивство якої жінку судили, вона народила від сина власника складу солі у Жовкві, Ігнаци Калза. Цей останній епізод зі свого досудового життя Марія описувала так: «Восени цього року вступила [на службу - I. Ч.] до Давида Калза власника складу солі в Жовкві. Там мала любовний стосунок з його сином

1 Оригінальною мовою кримінальних свідчень була польська. Тут і далі цитати подано в перекладі авторки. 
Ігнаци писарем з Суду. Від нього завагітніла, сказала про це йому, він мені, однак, погрожував, що мене застрелить, якщо не покину службу. Відійшла зі служби в Калза, як було ще зимно» [10, арк. 19]. Під час вагітності Марія працювала в різних місцях, народжувала дитину в шпиталі. Після виписки 3 лікарні жебракувала біля Руської церкви у Жовкві. Дитина постійно плакала через нестачу їжі. Змучена від цього Марія «розізлилася на дитину і кинула в студню недалеко церкви». Свій вчинок Марія пояснювала бідністю і неможливістю прогодувати дитину.

Бідність була найбільшим повторюваним виправданням жінок, що обвинувачувалися у дітовбивствах та підкиданнях/покиданнях дітей. Описуючи своє становище вони, як правило, акцентували на складності працевлаштування 3 дитиною, відтак ризику залишитися без даху над головою і жодних засобів до існування. У таких історіях жінки також наголошували на обставинах свого життя і передумовах, що спровокували злочин - сирітстві чи відсутності підтримки родини, відреченні чоловіка, що був батьком нешлюбної дитини. Якщо суду вдалося отримати свідчення названого батьком чоловіка, зміст його слів найчастіше опосередковано вписувався в заданий жінкою власний жертовний наратив. Названі батьками чоловіки, як правило, не заперечували наявність сексуального зв'язку з підозрюваними, однак при цьому майже завжди натякали на неморальний спосіб життя цих жінок, наявність «інших чоловіків» або ж прямо звинувачували їх у проституції.

Тон свідчень батька Маріїної дитини Ігнаци Калза тут буде пока- зовим. «Пригадую собі, - починав свою розповідь Ігнаци, - що перед роком служила у мого діда Ізраеля Бера Калза, в чийому домі я мешкаю дівчина на ім'я Маринка. Прізвища їі не пам'ятаю і не знаю чи називалася Петришак. Як собі пригадую служила вона близько 3 місяців і перед зимою зі служби пішла. 3 початком ї̈ служби я підтримував з тією служницею сексуальний зв'язок недовго, перестав з нею спати тому що переконався що їі цілими ночами нема в домі і боявся аби від неї якої хвороби не набрати. Що потім з тою служницею сталося того не знаю, бо я ніколи ї̈ потім не бачив...» [10, арк. 40]. Його інтерпретація їхніх взаємин (які Марія окреслила як «любовні» - I. Ч.) була констатацією соціальної прірви між службою i роботодавцями, відносини яких нагадували форму звичайної трансакції, де перші надавали послуги, а другі - ними користувалися. Відсутність будь-якого сентименту чи навіть його позірного вдавання зі сторони Ігнаци для захисту грала свою важливу роль, надаючи Маріїній безвиході підтвердження. На тлі його емоційної сухості її історія виглядала болючою, а відтак такою, якій можна співчувати - не лише через чоловікове відречення, а й через виразність соціальних дистанцій, які в таких контекстах ставали дуже очевидними.

Наявність сексуальних стосунків роботодавців зі служницями для тогочасного суспільства була доволі тривіальною історією [12]. Випадок Марії тут міг мало кого здивувати. У кримінальних справах такі сюжети, однак, набували нового звучання. У них романи господарів зі службою були трактовані не так в категоріях зневаженої моралі (вчинку проти 
релігії, інституту сім'ї, суспільних норм тощо), як крізь призму соціального визиску й нерівностей, породжених різницею базових можливостей одних та інших. Гуманізація права, ідеї жіночої емансипації, а також активне ангажування робітників в соціалістичні рухи, можемо припустити, дуже впливали на артикуляцію саме соціальних аспектів.

Вимагаючи від місцевої влади походження підсудних, так зване свідоцтво маєтку - документ про володіння ними якою-небудь власністю, - слідство, зазвичай, переконувалося в їх абсолютній бідності. Таким як Марія - дівчатам з багатодітних селянських сімей - від батьківського спадку, звично, діставалося куди менше, аніж їхнім братам. Патерналістська логіка спадкування по чоловічій лінії, мотивована потребою збереження основного селянського багатства - землі - у родині, в умовах звичного для селян земельного дефіциту, нерідко залишала доньок без землі як посагу, а відтак робила їх менш привабливими на матримоніальному ринку. За таких умов селянські доньки з бідних сімей поповнювали ряди низькооплачуваної домашньої служби, мігруючи до міст, чи наймаючись помічницями до більш заможних сільських господарів, або ж залишаючись у схожій ролі в успадкованому братом батьківському господарстві. Незаміжжя як характерна для більшості оскаржених у дітовбивствах обставина в очах суду, відтак, набувала пояснення не лише і не стільки особистої «трагедії» цих жінок, як результату їх невигідних соціальних та економічних позицій.
«Як дадуть шибеницю раз, то другий раз не дадуть»1

Характерною ознакою більшості свідчень жінок у справах про дітовбивства $\epsilon$ акцент на фатальності їх власної долі. Сліпа визначеність долі, чиїми жертвами називали себе ці жінки, для суду також мала свою логіку. Ї̈̈ закономірність визначало походження. Інтерес до родинних стосунків підсудної та її походження, за логікою суду, пояснював те, ким ця людина була, чи могла б бути. Часто доданими до кримінальних справ були метрики оскаржених, свідоцтва про хрещення, чи інші документи парафіяльного уряду, вірними якого вони вважалися. Такі документи мали багато пояснити про причини вчиненого злочину. Брак належного виховання, непевні обставини статевого дозрівання і поганий приклад служили причинно-наслідковим поясненням вчинку.

Нерідко оскаржені жінки аргументували свій злочин альтруїстичною метою - врятувати дитину від нужди, в якій перебували самі [13]. Марія Петришак, до прикладу, пояснювала, «що через матір є така нещаслива, бо їі мати таку дурну виховала, краще б зробила так, як вона зі своєю дитиною, то би сьогодні так не бідувала» [10, арк. 61]. Ймовірно такий аргумент працював. Суду було важливо побачити емоції в аргументації вчинку оскарженої, шукаючи у них драму «материнського інстинкту» і непростих життєвих обставин. Ступінь усвідомлення аморальності вчиненого підсудною ставав дуже вагомим аргументом при винесенні присуду. Тут йшлося не так про те, чи

\footnotetext{
1 Цитата зі свідчень Марії Петришак [10, арк. 61].
} 
визнавала жінка свою провину, - їх абсолютна більшість це робила, - a те, як вона описувала свій злочин. Емоційна скупість переказаного нею вчинку в очах слідства корелювала рівень її жорстокості, а відтак впливала на призначене покарання [14].

У справах про дітовбивства трапляються матеріали про судовопсихологічні експертизи емоційного здоров'я арештованих. Їх доцільність особливо артикулювалася у випадках вбивств, вчинених одразу після пологів. У формі запитань-відповідей жінки розповідали про своє життя, сімейні стосунки, ставлення до релігії, свого злочину, а також власні прогнози на покарання. Загальний тон цієї бесіди відображає висновок з експертизи Марія Петришак. Назагал визнаючи Марію здоровою, експерт підсумовував: «якщо не брати до уваги брак виховання вміє вона добре 10 божих заповідей, ходить до сповіді $i$ знає їі ціль і значення, знає що зле і що добре [...] має почуття суспільного порядку і злочину що загрожує карою, має почуття сорому і виразний слід особистої амбіцї̈, яка чи не переважила на терезах рішення про злочин» [10, арк. 65]. «Слід особистої амбіції», зчитаний 3 вибору позбутися дитини, а не залишитися з нею, мав означати те, що Марія як жінка вибрала себе, своє трохи менш нужденне життя без дитини, чим порушила нормальність природного материнського вибору.

Цікаво, що визначаючи зв'язок матері до дитини як природній чи вроджений, суду, однак, майже не йшлося про з'ясування того, чи була ця вагітність наслідком добровільних стосунків, чи зґвалтування. Визначальним був сам факт наявності нешлюбної дитини, за який жінка несла повну відповідальність, щонайперше у моральній площині. Аргументація її кримінальної вини за вчинений злочин, як і аргументація розуміння їі становища будувалася крізь одну й ту ж призму - призму моралі. Як не парадоксально, але на заграванні з мораллю жінки найчастіше і вигравали свої справи (чи зменшували суворість присудів), використовуючи ту ж лінію оборони, яку обвинувачення використовувало проти них - звинувачені у недостатній моральності жінки, натомість, натякали на подвійні стандарти останньої, що в різний спосіб міряла відповідальність жінки і чоловіка до народженої поза шлюбом дитини, знову і знову загострюючи на власній фінансовій непосильності виховати дитину самим.

Згідно з тогочасними суспільними нормами незаконнонароджені діти, звично, вважалися винятково жіночою «проблемою». Таке їх трактування закріплювали право і звичай, за яким все, що стосувалося контролю над народжуваністю належало до сфери компетенції жінок. У параграфі 165 Австрійського цивільного кодексу прописувалося, що позашлюбні діти мають носити родову назву матері й не можуть користуватися однаковими правами 3 шлюбними дітьми, зокрема мати право на сімейний титул батька і його соціальні привілеї. Обмеженими були i їхні права на батьківську спадщину (§ 754). Праводавці поступово намагалися хоча б мінімально забезпечити права матерів позашлюбних дітей. Про це, зокрема, свідчили параграфи Цивільного кодексу, що зобов'язували батька «звернути матері видатки на злоги та видатки на удержання їі на перші шість тижнів піс- 
ля злогів» (§ 167) i «покрити видатки на виживлення дитини» (§ 169) [15, c. 56]. Однак, як засвідчують опрацюванні справи, ці норми нечасто працювали. Практично у кожній історії $з$ сюжетом довготривалих стосунків матері з батьком дитини, жінки нарікали на відсутність з їхньої сторони матеріальної допомоги й вказували цю причину однією 3 тих, що спровокувала їх вчинити злочин.

Марія Петришак навіть не намагалася претендувати на допомогу батька дитини, очевидно наперед вбачаючи у таких спробах безрезультатність. Прийнята за норму елітарна думка про низьке походження служниць і вульгарні норми їх середовища служила вигідним обгрунтуванням їхньої можливої «вигоди» зі стосунків з роботодавцями. Ситуації, що здавалося мали б виглядати доволі тривіально: наділений владою і грошима чоловік користав зі свого становища, ініціюючи чи змушуючи до сексуальних стосунків підопічну йому жінку - у матеріалах слідства не були самоочевидними. Цікаво, що сільське походження, яке засвідчувала більшість оскаржених у дітовбивствах, служило достатнім поясненням їх сексуальної грамотності. В інтерпретації слідства низьке соціальне походження нерідко було асоційована з раннім початком статевого життя. Частково такі уявлення могли випливати зі статистики більш ранніх одружень у сільській місцевості на противагу місту [16]. Іншим можливим поясненням такої обставини могло бути також те, що поширені в національних літературах тогочасної Галичини романтичні наративи про «ідеальне і морально незаплямоване село» на противагу «брудному і здеморалізованому міс- ту» не цілком відповідали дійсності. Чи не найбільше тутешній myth of peasant virtue руйнувала статистика поширення венеричних захворювань, наприклад у сільських гірських районах провінції [17, p. 263].

\section{У пошуках кращого минулого}

Збір інформації про підозрювану особу передбачав цілий набір документів. Крім згаданих свідоцтв, що засвідчували майновий статус та походження, важливим документом кримінальних справ було також свідоцтво моральності - свого роду характеристика громади на оскаржену, видавана на вимогу суду начальником гміни, рідше - душпастирем парафії, до якої особа належала. В матеріалах слідства такі свідоцтва могли бути чи не єдиними, написаними руською/українською, документами. У свідоцтві моральності оцінювалося на скільки порядним був спосіб життя цієї людини, її вдача та публічна думка про неї серед громади («досить спокійна, була завжди працьовитою, послушною, тверезою і сумлінною»[18, арк. 35], «своєю поведінкою не давала ніколи іншим злого прикладу» [19, арк. 17], «3 точки зору моральності поводилася цілком добре - так що крім злочину дітовбивства попередньо порядною дівкою була» [20, арк. 33]). Показово, що у більшості справ свідоцтва моральності були позитивними, їх винятковість на цьому тлі верифікувалася лише багатослівністю опису надавача, його бажанням у такий спосіб «вплинути» на слідство.

Особлива увага суду була зосереджена також на показах свідків, які могли підтвердити чи заперечити заданий жінкою власний віктимний образ. Серед свідків найчастіше фігурували родичі, сусіди, роботодавці 
підсудної, а також випадкові свідки, що через збіг обставин ставали дотичними до справи. Якщо слідство назбирало достатньо аргументів на підтримку підозрюваної як «бідної» $\mathrm{i}$ «недосвідченої» дівчини, що дала себе намовити, спокусити чи використати, або людини, чиє життя ніколи не знало добрих прикладів (тут, головно, йшлося про неопіку батьків, або їх відсутність взагалі), судді могли бути дуже м'якими у своїх рішеннях. Розраховувати на особливе розуміння суду найчастіше могли недосвідчені дівчата, тобто ті, для яких вагітність, що привела їх до злочину, була першим сексуальним досвідом. Жінки, що до цього були матерям, чи про подробиці особистого життя яких, суду було відомо багато контроверсійного, мали набагато менше шансів на таке розуміння.

Виправдувальний вирок у справі Марії Петришак був до певної міри винятком. Попри те, що одностайності 12 членів суду присяжних так і не дійшли, проголосувавши на перше висунуте на голосування запитання 7 голосами «за» винуватість підсудної й 5 голосами «проти», друге необхідне для підтвердження голосування не набрало потрібної для обвинувачення кількості в 9 схвальних суддівських голосів. Був цей випадок, юридичною казуїстикою чи вдало зіграною ставкою на інститут суду присяжних визначити, очевидно, складно. Маючи 11 судимостей позаду Марія дуже відрізнялася від середньостатистичної жінки-дітовбивці. Для їх більшості інкриміноване обвинувачення ставало першим у житті, так само як звично першою була народжена дитина. Що ж тоді не переконало необхідну більшість у їі провині, а відтак потребі бути за це покараною?
Тюрма як (не)жіноче місце покарання

Відповіді на це запитання варто шукати у тому, що в'язниця, з одного боку, та поширений у суспільстві імідж дітовбивці як жінки, яка оступилася та морально занепала, 3 іншого, мало співвідносилися між собою. Для часто звинувачуваних в емоційності присяжних, картинку життя підозрюваних, конструйовану впродовж усього часу слідства з уламків розповідей про брак належного виховання і безпросвітні злидні, мало могло покращити тюремне середовище. У закладі карному для жінок імені Марії Магдалини, куди, можливо, потрапила б відбувати покарання Марія, їі віднесли б до групи досвідчених рецидивісток. Жінок, що потрапляли сюди вперше, і тих, хто мав за плечима тюремне минуле, звично розділяли, очевидно вбачаючи у цьому превентивні заходи від подальшого входження недосвідчених в кримінальне середовище [21].

Чомусь не особливо розраховували присяжні й на дієвість Маріїного навчання, як одного 3 методів в'язничної поправи, пропонованого, до прикладу, утримуваним у Закладі карному для жінок імені Марії Магдалини. Ув'язнені в «Магдаленках» ставали ученицями народної 2класової школи - базової навчальної одиниці тогочасної австрійської освітньої системи, - що діяла при в'язниці. Ймовірно таке навчання мало б бути більш ніж необхідним, оскільки більшість жінок на досудових процедурах засвідчувала, що не вміють ні писати, ні читати. Серед 10-ти предметів навчального курсу, що викладали монахині Закладу, були: наука релігії, читання, писання (йшлося про одну з трьох мов на ви- 
бір: польську, руську/українську чи німецьку), рахунки, природознавство, господарство, малювання, співи, рукоділля та гімнастика. Останні чотири предмети залишалися незаповненими, очевидно їх і не викладали.

Можливо такий скепсис присяжних був мотивований наочною несумісністю ідеї та практики в'язниці. Зрештою про скептичні сприйняття поправи своїх вихованок вчительками закладу свідчить загальний тон, ведених ними класних журналів. У графі «зауваги вчительки класу», що йшла окремим рядком і заповнювалася вибірково, записували, зазвичай, лише негативні відгуки: «дуже зухвала й вперта», «через злий приклад, який постійно давала через опір і брехню вилучена з класу», «дуже слабких здібностей», «загалом не вчиться через лінь» і т.і. Нерідко у цій графі вчительки подавали й причину неуспіху в науках, відсутності на уроках чи відрахування з навчання - як правило, через хворобу й перебування в лікарні, або ж через фізичне каліцтво чи розумове відставання [22].

Зрештою, дбаючи про релігійну складову побуту своїх підданих, монахині милосердя не хотіли молитися 3 ними в одній капличці. Окрема капличка для ув'язнених була створена в стінах Костелу святої Марії Магдалини з одного із захристій. За домовленістю 3 тогочасним ксьондзом костел відпускав частину свого приміщення під в'язничну капличку в обмін на прання костельних речей та миття храму раз на рік, що його монахині мали б забезпечити. 3 того часу функціонування такої каплички в парафіяльному храмі ставало об'єктом численних суперечок між костелом, що намагався повернути свою власність, та монахинями, які на це не погоджувалися [11].

Висновки. Соціальна стигма, що супроводжувала злочинців їхнє життя, для оскаржених у дітовбивствах жінок означала не лише ізоляцію й осуд, а й віктимізацію. Традиційна патріархальна дихотомія: жінка природне, чоловік - соціальне [23], у цих справах радше грала на користь жінок, аніж проти них. Схильним до співчуття оскарженим у дітовбивствах, звично, був, запроваджений на хвилі гуманізації права, суд присяжних. Тенденція до пом'якшення присудів найчастіше узгоджувалася 3 прийняттям того факту, що у трактуванні більшості суспільства, так і згідно з офіційним законодавством, незаконнонароджені діти були такими, які більшою мірою належали своїм матерям, аніж батькам. Акцентована підсудними бідність як пояснення свого злочину опосередковано підкреслювала саме цю обставину, загострюючи тим самим не лише на соціальних, а й на статевих нерівностях. Разом з тим, перевага дискурсу «жертви обставин» у стосунку до вчинених жінками дітовбивств була по своїй суті дуже контроверсійною, оскільки, з одного боку, позбавляла цих жінок самої можливості свідомого вибору (коли брати до уваги факт, що злочин все ж не був єдиною, а лише однією із обраних опції), а 3 іншого, жертовний наратив робив наголошувані нерівності артикульованими, а відтак втягував їх у предмет дискусії. Чи було це результатом впливу ідей емансипації чи наслідком вдало вибраних стратегій захисту, очевидно, залишається під знаком запитання. Однак, очевидним видається факт, що частина жінок 
зуміла скористатись у суді обставинами своєї законодавчо закріпленої правової нерівноправності та існуючих гендерних упереджень.

\section{Список використаних джерел}

1. Schwan A. Convict Voices: Women, Class and Writing about Prison in 19 Century England. University of Massachusetts Press, 2014. P. 1-2.

2. Кісь О.Жіноча історія як напрямок історичних досліджень. Украӥнський історичний журнал. 2012. № 2. С. 171.

3. У цьому контексті моє дослідження буде у паралелі з поставленим свого часу Мішелем Фуко запитанням: чи увесь юридичний апарат, начебто задуманий передбачати й зменшувати порушення закону, не був, натомість, задизайнованим для того, аби організовувати незаконність? (Детальніше див.: Michel Foucault. Alternatives to the Prison: Dissemination or Decline of Social Control? Theory, Culture \& Society. 2009. Volume 26. Issue 6. pp. 12-24).

4. Серед досліджень інституту в'язниці у XIX ст. у стосунку до ЦентральноСхідної Європи див.: Ackermann F. Territorialisation and Incarceration: The Nexus between Solitary Confinement, Religious Praxis and Imperial Rule in nineteenth-century Poland and Lithuania. Acta Poloniae Historica 118 (2018). Str. 5-37; Bruce F. Adams. The Politics of Punishment: Prison Reform in Russia, 1863-1917. Northern Illinois University Press, 2011. На предмет жіночого кримінального досвіду, зокрема, див.: Sharon A. Kowalsky. Deviant Women: Female Crime and Criminology in Revolutionary Russia, 1880-1930. Northern Illinois University Press, 2009; Richard J. Evans. Tales from the German Underworld. Crime and Punishment in the nineteenth century. Yale University Press and New Haven and London, 1998.

5. Див. детльніше: Wingfield Nancy M. World of Prostitution in Late Imperial Austria. Oxford University Press, 2017; Wilson Tracie L. Migration, Empire, and Liminality. Sex trade in the borderlands of Europe. Aspasia. The international yearbook of Central, Eastern, and Southeastern European women's and Gender history. Vol. 11. 2017. P. 71-96; StauterHalsted K. The Devils Chain: Prostitution and Social Control in Partitioned Poland. Cornell University Press, 2015; Nautz J. The Effort to Combat the Traffic on Women in Austria before the First World War. Journal for Police Science and Practice. 2012. Vol. 2. P. 82-95.

6. Rocznik statystyki Calicyi / Wydany przez Krajowe biuro statystyczne pod kierunkiem Dr. Tadeusza Rutowskiego. Rok III. 1889-1891. Lwów, 1891. S. 378; Ibid. Rok IV. 1892-1893. Lwow, 1893. S. 356; Podręcznik statystyki Galicyi / Wydany przez Krajowe biuro statystyczne pod redakcyą Tadeusza Pilata. Tom VI. Cześć druga. Lwów, 1901. S. 326; Ibid. Tom VII. Cześć druga. Lwów, 1904. S. 322; Ibid. Tom VIII. Cześć druga. Lwów, 1908. S. 326.

7. Див.: Padraic Kenney. Dance in Chains: Political Imprisonment in the Modern World. NY: Oxford University Press, 2017; Кісь О. Українки в ГУЛАГу: вижити значить перемогти / Наук. ред. С. Павлюк. НАН України. Інститут народознавства. Львів: Інститут народознавства, 2017; Anna Muller. If the Walls Could Speak: Inside a Women's Prison in Communist Poland. Oxford University Press, 2018. 320 p.

8. Див.: Księżopolska-Breś A. Odpowiedzialność karna za dzieciobójstwo w prawie polskim. Warszawa, 2010; Brzezińska J. Dzieciobójstwo w regulacjach wybranych państw Europy Zachodniej od starożytności do 1914 r. Wrocławskie Studia Erazmiańskie. Zeszyty Studenckie, 2009. S. 275-290.

9. Maciej M. Gondek. Austriacka procedura karna z 1853 i 1873 roku w praktyce orzecznictwa sądów krakowskich. Studia z Dziejów Państwa i Prawa Polskiego XVI. 2013. 
No 1. S. 265. Див.: Tomczyk R. Proces karny w monarchii Habsburskiej. Od drugiej polowy XVIII wieku do 1918 r. Edukacja humanistyczna. Nr.1 (28). Szczecin, 2013. S. 67-79.

10. Центральний державний історичний архів України у Львові (ЦДІА у Львові). Ф. 152 (Крайовий суд, м. Львів). Оп. 2. Спр. 23045. (Справа Петришак Марії, жительки м. Львова, обвинуваченої у вбивстві своєї дитини, 1906).

11. Archiwum Główny Akt Dawnych w Warszawie (AGAD). Zespól 305 (C. K. Ministerstwo Sprawiedliwości). Sygn. 39. Tytuł [Więziennictwo we Lwowie: Zakład Karny dla kobiet, 1887-1912]. К. 1253-1260.

12. Див. детальніше: Poniat R. Służba domowa w miastach na ziemiach polskich od połowu XVIII do końca XIX w. Warszawa. 2014. 328 s.

13. Частково цим можна аргументувати порівняно м'який вирок, до прикладу, у справі Анни Лабик. Жінку за вбивство одного з народжених нею двійнят - хлопчика і дівчинки, - засудили до 4-ох місяців важкого ув'язнення. На зізнанні оскаржена пояснювала, що «вибрала дівчинку бо хлопця ліпше любила і міркувала, що хлопець легше дасть собі раду на світі» (Детальніше див.: ЦДІА у Львові. Ф. 152. Оп. 2. Спр. 16946. Арк. 9. (Дело по обвинению Лабик Анни в детоубийстве, 1894)).

14. Наприклад, у протоколі допиту, оскарженої за дітовбивство, Марії Бабік кілька разів наголошувалося на тому, що жінка «без жалю» дивилася на те, як ії дитина тоне. У результаті Марія отримала вирок у вигляді смертної кари через повішання, який згодом замінили на 10-річне тюремне ув'язнення. Можемо припустити, на суворість покарання вплинув факт недоведеної абсолютної бідності засудженої. Підозра про володіння Марією частиною грунту, який вона не схотіла переписати на свого швагра в обмін на можливість залишитися в його домі з дитиною, також могла відіграти свою роль. (Детальніше див.: ЦДІА у Львові. Ф. 152. Оп. 2. Спр. 14181. Арк. 8 (Справа Бабік Марії, жительки с. Свидниця, обвинуваченої у дітовбивстві, 1872).

15. Див. детальніше: Цивільне право. Видав С. Дністрянський. Відень, 1919. T. 1. C. 56

16. За статистикою найбільший відсоток жінок створювали подружжя у віковому проміжку від 20-24 років (Podręcznik statystyki Galicyi wydany przez Krajowe biuro statystyczne / Pod red. Tadeusza Pilata. Lwów, 1908. T. 8. Cz. 1. S. 44.). Середній вік одружень у великих містах, як правило, був вищим, зокрема у Львові за час 18811893 pp. він становив: для чоловік - 33, для жінок - 28 років (Детальніше див.: Lwów w cyfrach. Z drukarni «Dziennika Polskiego» / Pod zarządem Fr. Kattnera. Lwów, 1894. S. 19).

17. Stauter-Halsted K. The Devils Chain: Prostitution and Social Control in Partitioned Poland. Cornell University Press, 2015. P. 263.

18. ЦДІА у Львові. Ф. 152. Оп. 2. Спр. 18163. Арк. 35 (Справа Табаки Анни, жительки с. Поделицика, обвинуваченої у дітовбивстві, 1897-1900).

19. ЦДІА у Львові. Ф. 152. Оп. 2. Спр. 25015. Арк. 17 (Справа Мельник Катерини, обвинуваченої в дітовбивстві, 1910).

20. ЦДІА у Львові. Ф. 152. Оп. 2. Спр. 19366. Арк. 33 (Справа Війтик Варвари, жительки с. Корчмин, у дітовбивстві, 1899).

21. Оскаржена за дітовбивство Матрона Премудрак, до прикладу, на слуханні свідчила п'яною, оскільки «баби з якими сиділа в арешті дали три кілішки горілки», i намовляли признатися, що вона задушила народжене нею у лісі немовля. Однак те, чи робили вони це, керуючись бажанням нашкодити чи допомогти, залишається спірним запитання. Зважаючи на умови, якими звично апелювали в пом'якшенні вини, факт такої намови цілком спокійно можна було б вважати порадою. (Детальніше див.: ЦДІА у Львові. Ф. 152. Оп. 2. Спр. 18161. Арк 5 зв. (Справа Премудрак Матрони, жительки м. Потелич, обвинуваченої у дітовбивстві, 1897). Спільний час у тюрмі ставав «небезпе- 
чним» радше з огляду на знайомства, які там зав'язувалися і практики, яких там можна було навчитися. Засуджені у 1895 році за пограбування львівських крамниць дорогих тканин Рейзля Голд і Файга Лая Адлер познайомилися саме у в'язниці в часі своїх попередніх ув'язнень. (Детальніше див.: ЦДІА у Львові. Ф. 152. Оп. 2. Спр. 17664. Арк. 21 (Дело по обвинению торговки Адлер Файги и др. в краже ткани, 1895)).

22. AGAD. Zespól 305 (C.K. Ministerstwo Sprawiedliwości). Sygn. 34. [Więziennictwo we Lwowie] 1880-1913. K. 157-211.

23. Ортнер Ш. Чи співвідноситься жіноче 3 чоловічим як природа 3 культурою? Гендерний підхід: історія, культура, суспільство / За ред. Л. Гентош, О. Кісь. Львів, 2003. С. 134-149.

\section{References}

1. Schwan, A. (2014). Convict Voices: Women, Class and Writing about Prison in 19 Century England. University of Massachusetts Press, 1-2.

2. Kis, O. (2012). Zhinocha istoriia yak napriamok istorychnykh doslidzhen. Ukrainskyi istorychnyi zhurnal, 2, 171 [in Ukrainian].

3. See: Foucault, M. (2009). Alternatives to the Prison: Dissemination or Decline of Social Control? Theory, Culture \& Society. Volume 26. Issue 6. PP. 12-24.

4. See: Ackermann, F. (2018). Territorialisation and Incarceration: The Nexus between Solitary Confinement, Religious Praxis and Imperial Rule in nineteenth-century Poland and Lithuania. Acta Poloniae Historica. 118, 5-37; Bruce, F. A. (2011). The Politics of Punishment: Prison Reform in Russia, 1863-1917. Northern Illinois University Press; Sharon A. Kowalsky (2009). Deviant Women: Female Crime and Criminology in Revolutionary Russia, 1880-1930. Northern Illinois University Press; Richard J. Evans (1998). Tales from the German Underworld. Crime and Punishment in the nineteenth century. Yale University Press and New Haven and London.

5. Wingfield, N. M. (2017). World of Prostitution in Late Imperial Austria. Oxford University Press; Wilson Tracie L. (2017). Migration, Empire, and Liminality. Sex trade in the borderlands of Europe. Aspasia. The international yearbook of Central, Eastern, and Southeastern European women's and Gender history. Vol. 11. P. 71-96; Nautz, J. (2012). The Effort to Combat the Traffic on Women in Austria before the First World War. Journal for Police Science and Practice. Vol. 2. P. 82-95.

6. Kenney, P. (2017). Dance in Chains: Political Imprisonment in the Modern World. NY: Oxford University Press; Kis, O. (2017). Ukrainky v HULAHu: vyzhyty znachyt peremohty. Instytut narodoznavstva. Lviv [in Ukrainian]; Muller A. (2018). If the Walls Could Speak: Inside a Women's Prison in Communist Poland. Oxford University Press.

7. Księżopolska-Breś, A. (2010). Odpowiedzialność karna za dzieciobójstwo w prawie polskim. Warszawa; Brzezińska J. (2009). Dzieciobójstwo w regulacjach wybranych państw Europy Zachodniej od starożytności do 1914 r. Wrocławskie Studia Erazmiańskie. Zeszyty Studenckie, 275-90.

8. Maciej M. Gondek (2013). Austriacka procedura karna z 1853 i 1873 roku w praktyce orzecznictwa sądów krakowskich. Studia z Dziejów Państwa i Prawa Polskiego XVI, 1, 265.

9. Poniat, R. (2014). Służba domowa $w$ miastach na ziemiach polskich od połowu XVIII do końca XIX w. Warszawa.

10. Stauter-Halsted, K. (2015). The Devils Chain: Prostitution and Social Control in Partitioned Poland. Cornell University Press.

11. Ortner, Sh. (2003). Chy spivvidnosytsia zhinoche $\mathrm{z}$ cholovichym yak pryroda $\mathrm{z}$ kulturoiu? Gendernyi pidkhid: istoriia, kultura, suspilstvo. Lviv [in Ukrainian]. 
I. Cherchovych, PhD in History, Independent Researcher

e-mail: ivankacherchovych@gmail.com; ORCID ID: 0000-0003-3078-7003

\section{Convict Voices: Women and Infanticide in Eastern Galicia at the turn of the 19th - 20th centuries (case study)}

Criminal cases against women accused of infanticide were analysed in this article. My research focus was concentrated on the language of criminal cases in regards to women and most specific «women' crime». I am intended to show how did the accused women shape their crimes into a story and what these stories mean, how they realized their «victimity» and when they used it? I try to demonstrate how women, who often by default were denied the opportunity to choose according to widely spread perception about mandatory natural women crime conditionality and potential deviancy of women, were able to take advantage of that judgement.

The story of Mariya Petryshak provided in this article fall into genre of the "microstudy" - the history of individuals, small communities, exclusiveness or randomness, examples of which shed light on many aspects of Galician life during the late XIX century: from the most obvious like functioning of the punishment system in regards to women in the Habsburg time to less obvious details of everyday life one of the most marginalized groups in that society. In the criminal cases women tented to be both unfortunate (due to the circumstances that pushed them to commit a crime or the hostage of which they became) and guilty (due to their own excessive desires, passions or expectations). By coordinating these two parallels with real women, court' decisions often chose quite opposite interpretations of the same crime, creating a paradox to some extent.

The social stigma accompanying the criminals during their lives meant for women not only isolation and disapproval but also victimization, which was particularly noticeable in the cases of infanticide. The tendency to commute the sentence for women, who committed crimes against their illegitimate children most often derived from the understanding of the fact that in the treatment of the majority of society, and according to law, illegitimate children were those who belonged more to their mothers than to their fathers. It is not an accident that such understanding was simultaneous with increase of women's movements in Galicia of that time and more frequent involving women from working class into such activity.

Keywords: women; prison; infanticide; court investigation; Eastern Galicia. 